highly technical ones from which only excerpts will be published. Every separate work will be supplied with an introduction by an expert in the particular problem, who is in many cases responsible for the actual translation, or for editing it, as well as for commentaries that serve to explain various points, to bring up to date the nomenclature of plants and animals, etc. The first volume that appeared in 1935 contains the "Journal of Researches, etc." supplemented by the "Diary" (as published by Norah Barlow); the second, printed in 1936, includes a series of zoological works, the book on earthworms, and a series of geological works, especially that on the formation of coral reefs. The editorial work is done very thoroughly, but the appearance of the book leaves much to be desired, as the paper (particularly in the first volume) is of indifferent quality, affecting the illustrations, which are reproduced mostly from original English editions. When (and if) all the promised twelve volumes are published, it will be possible to judge the whole enterprise in greater detail.

\section{Recent Acquisitions at the Geological Museum}

The Geological Museum has recently put on exhibition two new dioramas illustrating the occurrence and exploitation of gold ore at the Lake Shore mine in the Timiskaming District of Ontario. This mine is the largest gold producer on the American continent, and one of the most important in the world. One of these dioramas introduces a new technique, in illustrating the geological structure to a depth of 4,500 feet, as well as the general surface topographic features. The dioramas have been presented by Mr. Harry Oakes, who originally staked the property. Among other recent additions to the collections are a jade hei-tiki, carved by the Maoris, the gift of H.M. Queen Mary; a very extensive collection of polished Italian marbles, presented by Mr. Percy C. Webb; and a magnificent group of deeply coloured amethyst crystals from Brazil, loaned by the managers of the Royal Institution. The Geological Society of London has presented a group of large pillars of basalt, from the Giant's Causeway in Antrim; an Ichthyosaurus from the Lower Lias of Barrow-on-Soar; a very fine slab of Wenlock Limestone with Periechocrinus moniliformis, etc., collected by the late Earl of Dudley ; and a beautiful specimen of Pentacrinus briareus Miller from the Lias of Lyme Regis, collected by Sir H. T. de la Beche, the first director of H.M. Geological Survey. Within recent months, the Museum has added to its permanent exhibits on economic geology displays on abrasives, moulding sands, refractory materials, and other subjects of industrial interest.

\section{Codes Used in Weather Forecasts}

"Wireless Weather Messages, 1937" (Publication M.O. 252, tenth edition. London: H.M. Stationery Office. $1 s, 6 d$. net) has the sub-title "Particulars of Meteorological Reports issued by wireless telegraphy and wireless telephony in Great Britain, Gibraltar, Malta, Middle East and Iraq", and this defines its scope. It incorporates changes in some of the specifications of the International Code used for meteorological messages that were adopted at the International Meteorological Conference held at Warsaw in September 1935, changes which came into operation on January 1, 1937. There are two sections giving, respectively, details of the codes used for weather forecasts for aviators and details of the codes used for messages giving special information supplementary to routine reports for aviation. These sections follow the main body of the publication dealing with the main transmissions from shore stations and ships. In spite of some economy of space that has been introduced in setting out the details of individual transmissions, this publication now contains about ninety pages, and its growth in recent years corresponds with that of aviation and of the international exchange of meteorological information.

\section{Carnegie Trust for the Scottish Universities}

The Carnegie Trust for the Universities of Scotland has recently published its report for 1935-36. Grants to universities and extra-mural institutions amounted to $£ 51,460$, expenditure on assistance in payment of class-fees to $£ 53,971$, grants under the Trust's scheme for endowment of research to $£ 17,880$. The progress of recovery from economic and industrial depression in Scotland is reflected in the exceptional number of resignations of fellows and scholars due to their appointment to paid positions. Of thirty-two fellows and scholars in chemistry, organic and physical, fifteen resigned, some almost at the commencement of their appointment periods. Another indication of prosperity is the sharp rise in the amount of voluntary repayments by former recipients of aid from the Trust. These repayments amounted. to $£ 2,362$, the largest amount so received by the Trust since 1928-29, and only exceeded in that year and 1926-27. The aggregate amount of such repayments since the inauguration of the scheme in 1901 is $£ 38,000$.

\section{Rearing Marine Organisms in the Laboratory}

The Aquarist and Pond-Keeper of JanuaryFebruary 1937, besides a number of other interesting papers, contains an article by Mr. Douglas P. Wilson, naturalist at the Marine Biological Laboratory, Plymouth, on the plunger jar for rearing marine organisms. This is a piece of apparatus much used in the Plymouth Laboratory, originally planned and used by Mr. E. T. Browne for rearing medusæ, the main idea being to create a definite rhythmical movement in the aquarium by means of a glass plate, the plunger, manipulated by a siphon. All workers at Plymouth are familiar with the plunger jar, and it is now used in many laboratories. Numerous wellknown researches have been successfully conducted by its aid; echinoderms, molluscs, crustaceans, worms, have all been reared, and it is fit that the plunger-jar should be introduced to all those who wish to keep marine animals. Mr. Wilson, who has himself reared successfully several sea-worms from the egg, describes how this can be done. 